\title{
Perspective of corporate governance and ethical issues with profit sharing investment accounts in Islamic banks
}

Article

Accepted Version

Alhammadi, S., Archer, S., Padgett, C. and Abdel Karim, R. A. (2018) Perspective of corporate governance and ethical issues with profit sharing investment accounts in Islamic banks. Journal of Financial Regulation and Compliance, 26 (3). pp. 406-424. ISSN 1358-1988 doi: https://doi.org/10.1108/jfrc-012017-0014 Available at https://centaur.reading.ac.uk/78845/

It is advisable to refer to the publisher's version if you intend to cite from the work. See Guidance on citing.

To link to this article DOI: http://dx.doi.org/10.1108/jfrc-01-2017-0014

Publisher: Emerald

All outputs in CentAUR are protected by Intellectual Property Rights law, including copyright law. Copyright and IPR is retained by the creators or other copyright holders. Terms and conditions for use of this material are defined in the End User Agreement.

www.reading.ac.uk/centaur 
Central Archive at the University of Reading

Reading's research outputs online 


\title{
How "Profit Sharing" are they? Profit Sharing Investment Accounts in Islamic Banks
}

\author{
Perspective of Corporate Governance and Ethical Issues \\ Salah Al Hammadi, Simon Archer ${ }^{1}$, Rifaat Ahmed Abdel Karim and Carol Padgett
}

\begin{abstract}
Islamic banks (IBs) cannot pay or receive interest. Hence, in lieu of conventional interest-bearing deposit accounts, they commonly offer a type of account, an "investment account", the holders of which are paid a share of the profits earned by the bank on the assets funded by their deposits. The contractual basis of these investment accounts is an Islamic contract known as Mudarabah, which is a type of partnership between one or more providers of funds (known as the Rabb al Mal) as sleeping partners and a managing partner (known as the Mudarib) (in this case the bank) who is the active partner and invests time and effort but does not provide funds. Having no funds invested, the Mudarib is not exposed to financial losses, but may lose his time and efforts (an opportunity loss). The sleeping partners are, by contrast, exposed to losses on the assets financed by their funds, unlike conventional depositors who are only exposed to losses if the bank becomes insolvent. This use of the Mudarabah raises some thorny issues of corporate governance, regulation and the equitable treatment of unrestricted investment account holders (UIAH), who as profit-sharing and loss bearing stakeholders in IBs are nevertheless without any governance rights. The bank's policies, as set by its board of directors, are likely to reflect the risk-return preferences of its shareholders, who hold governance rights, rather than those of its UIAH. The former will typically have a significantly greater risk appetite than the latter. Given the prevalence of commingling by IBs of Mudarabah funds with shareholders' own funds and other funds under the bank's control on which it earns profits for shareholders (such as those of current accounts), this raises an issue of the extent to which asset allocation reflects the preferences of UIAH. The issue of the equitable treatment of UIAH is not merely one of corporate governance but also one of business ethics. An analysis presented in this paper of financial data from a substantial sample of Islamic banks indicates that the concept of "profit sharing" tends to be stretched by IBs, exercising the discretion given to them by the form of Mudarabah that they use, to a point where it is questionable whether the term "profit sharing" is really appropriate, and whether the UIAH are treated equitably in a significant proportion of cases.
\end{abstract}

\footnotetext{
${ }^{1}$ Corresponding author (s.archer@blueyonder.co.uk). This paper is substantially based on a thesis submitted by Salah Al Hammadi as a PhD candidate at the ICMA Centre, Henley Business School, University of Reading, UK, supervised by Simon Archer and Carol Padgett. Rifaat A A Karim is a Visiting Professor at the ICMA Centre.
} 


\section{Introduction}

Islamic Banks (IBs) have developed Profit Sharing Investment Accounts (PSIA) for customers' savings and repository accounts in place of conventional interest-bearing deposit accounts, in order to mobilise funds on which IBs and their customers can earn Shari'ah-compliant returns (Archer et al., 2010). Customers deposit their funds in so-called "profit sharing investment accounts" as capital providers, and the bank invests these funds on the customers' behalf in return for a share of the profit or for a fee as remuneration for management. There are two types of PSIAs:

1. A restricted profit sharing investment account (RPSIA), a separately managed fund that is not commingled with other funds of the IB. This is similar to mutual funds and is generally considered by Islamic banks for the purpose of financial reporting as "off balance sheet funds" under management.

2. An unrestricted profit sharing investment account (UPSIA) is an account such that an Islamic bank has full discretion to utilise and invest the UPSIA funds. These accounts are widely used by IBs in place of conventional interest-bearing deposits.

The contractual bases for these types of account are the Mudarabah or Wakalah contracts, where in a Mudarabah the customers as Rabb al Mal (provide capital) and the bank provides work as Mudarib (entrepreneur or asset manager) and shares profit, or the bank in Wakalah acts as Wakeel (agent) and receives a fee plus (typically) a performance related bonus (Archer et al., 1998).

The Mudarabah contract, like the Commenda contract used by medieval Italian traders, was used originally for financing trade ventures in which the trader purchased a cargo which was transported by ship or caravan to a destination where the goods were sold and other goods might be purchased for sale in the home market. The profit on these transactions was divided between the sleeping partners (financiers) and the trader according to contractually agreed ratios. Rich financiers could diversify their risk by investing in a number of such ventures, as losses might naturally occur.

In such circumstances, it was normal that the financiers should be sleeping partners, as they were not in a position to play an active role in the venture. Moreover, each Mudarabah (or Commenda) was a one-off venture with a final settling-up between the partners at its conclusion.

IBs have adapted this form of contract to be the basis of "investment" products which comply with the Islamic (Shari'ah) prohibition of interest. A Mudarabah used for this purpose is not a one-off venture, but may continue for an extended period so long as the account holder keeps funds in the account. One such adaptation has been the product developed as a Shari'ah compliant alternative to the conventional interest-bearing deposit account which is generally known as the Unrestricted Profit Sharing Investment Account (UPSIA), because the contract gives the bank an unrestricted mandate to invest the funds as it sees fit. Normally, the bank commingles the assets financed by the Mudarabah with the other assets on its balance sheet. Thus, the asset risk of the combined pool is shared between the shareholders and the Unrestricted Investment Account Holders (UIAH) pro-rata to the respective amounts of funds. The nearest parallel to this in conventional banking (albeit without commingling) is private banking investment accounts offered to so-called High Net Worth Individuals (HNWI) who typically have a certain appetite for risk if the potential return is high. However, the customers using UPSIA (UIAH) are typically far from having the risk-return preferences of HNWI, and would normally seek a low-risk low-return deposit-like account. 
Hence, as we explain further below, this adaptation of the Mudarabah raises some thorny issues of corporate governance, regulation and the equitable treatment of UIAH, who as profit-sharing and loss bearing stakeholders in IBs are nevertheless without any governance rights (see Archer, Al-Deehani and Karim 1998) - a serious anomaly, as Williamson's (1996) analysis implies. The bank's policies, as set by its board of directors, are likely to reflect the risk-return preferences of its shareholders, who hold governance rights, rather than those of its UIAH. The former will typically have a significantly greater risk appetite than the latter. Given the prevalence of commingling, this raises an issue of the extent to which asset allocation reflects the preferences of UIAH.

The issue of equitable treatment of UIAH is not merely one of corporate governance but also one of business ethics. As it happens, analysis of financial data from a substantial sample of Islamic banks indicates that the concept of "profit sharing" tends to be stretched by IBs, exercising the discretion given to them by the form of Mudarabah that they use, to a point where it is questionable whether the term "profit sharing" is really appropriate, and whether the UIAH are treated equitably in a significant proportion of cases.

The rest of this paper is organised as follows. Section 2 explains in more detail how UPSIA are used by IBs as an Islamic (i.e. Shari'ah compliant) alternative to conventional deposit accounts. Section 3 is a brief literature review. Sections 4 and 5 describe an empirical study of profit sharing applied to UPSIA as practiced by a substantial sample of IBs: first by comparing the rates of return paid to shareholders (return on equity - ROE) and to UIAH (return on balance invested) on a risk-adjusted basis, i.e. taking account of the variability (standard deviation) of the respective rates of return; secondly by analysing the extent to which the differences between the shareholders' ROE and the UIAHs' rates of return can be explained by a set of corporate governance and financial variables. This is continued in Section 6 by a similar analysis of riskadjusted rates of return, but focussing on the shareholders' dividend yields rather than on return on equity. Section 7 sets out our conclusions.

\section{UPSIA as an Alternative to Conventional Deposit Accounts}

IBs operate in accordance with Islamic religious law (the Shari'ah), and to this end they employ a number of contractual forms which are set out in Islamic commercial jurisprudence (Fiqh al Muamalat) and are known as the 'nominate contracts'. One of these is the Mudarabah, which they have adapted to provide an alternative to conventional interest-bearing deposit accounts, as described in Section 1.

The basic adaptation is that, whereas the traditional Mudarabah was used for financing oneoff ventures which concluded with a single, final profit calculation, the IBs employ it for financing ongoing fund management activities which involve periodic (e.g. monthly, quarterly or annual) profit calculations. This raises, inter alia, the issue of the treatment of unrealised gains and losses.

In addition, as noted above, the assets financed by the funds of the Mudarabah are typically commingled in a pool with the other assets managed by the IB which appear on its balance sheet, namely the assets financed by the funds of current account holders and the shareholders' funds. Thus, the UIAH are exposed to the same asset risk as the shareholders.

A further, and crucial, adaptation is the practice of "smoothing" the returns payable to the UIAH, so that they resemble more closely the returns on conventional deposit accounts. This is achieved by using two types of method. In the first place, the contractual Mudarib share of 
income from the Mudarabah is set at a high level, in some cases as high as $70 \%$ or even higher ${ }^{2}$. This gives the IB as Mudarib the scope to take a lower share if the Mudarabah income is low, in order to avoid paying a very low return to the UIAH. This practice has the effect of increasing the variability or riskiness of the shareholders' returns while reducing that of the UIAHs' returns, an effect known as Displaced Commercial Risk (DCR) ${ }^{3}$.

Secondly, IBs use two types of reserve accounts to which transfers may be made in the more profitable years, thus reducing the distributable profits, and from which transfers may be made to increase distributable profits in poor years. These reserve accounts are generally known as the Profit Equalisation Reserve (PER - a misleading term as it is only the distributable profits which are smoothed) and the Investment Risk Reserve (IRR) ${ }^{4}$. With the exception of IBs in a few countries, the transfers into and out of these reserve accounts are not disclosed in IBs' financial statements, so that there is a lack of transparency with respect to the underlying profit performance.

Some national banking supervisors encourage such practices, and make it clear to IBs that they do not expect any losses to be passed on to UIAH. This can be avoided by use of the IRR provided the balance on this account is sufficient. The rules of the Mudarabah contract do not permit the Mudarib to cover losses to the UIAH by making transfers from shareholders' profits or reserves.

In 2014, Bank Negara Malaysia (BMN - the country's central bank), which used to be one such supervisor, changed its policy regarding "profit smoothing practices". These are now prohibited by paragraph 13.5 of the BNM's March 2014 Policy Document Investment Account, issued following the passage of the Malaysian Islamic Financial Services Act 2013. It is not clear that this change has been welcomed by the market, since there has been an increasing use of an alternative form of deposit account, based on Commodity Murabahah Transactions (CMT). CMT-based term deposits are placed by a customer who undertakes to purchase an amount of a commodity of a certain value which it then sells to the IB on credit for a specified term by means of Murabahah, with a mark-up. The IB then sells the commodity in the spot market for cash to generate the deposit. The Murabahah mark-up constitutes the provider of funds' return on the funds. Such transactions do not meet with the approval of a number of Shari'ah scholars (acknowledged experts in Shari'ah law), but are approved by those in some countries, including Malaysia.

\section{Literature Review}

There is hardly any empirical literature on the practice of profit sharing by IBs. Al-Sadah (2008), examined the corporate governance of IBs, including its effects on the practice of profit sharing, using in-depth case studies of 3 IBs. His findings were consistent with the description in Section 2 of the practice of "smoothing" and the exercise of discretion by IBs' management in "managing" the share of profits paid to UIAH. Alaeddin (2015), examines the effectiveness

\footnotetext{
${ }^{2}$ In 2014 and 2015 Bahrain Islamic Bank (BIB) charged 85\% as Mudarib share. This was reduced in 2016 to $56.88 \%$. (Source: BIB annual reports.)

${ }^{3}$ This terminology was first coined by Simon Archer and R A A Karim when the latter was the Secretary-General of Accounting and Auditing Organization for Islamic Financial Institutions (AAOIFI) and S Archer was a consultant to it.

${ }^{4}$ The terminology of both reserves was first coined by Simon Archer and R A A Karim when the latter was the Secretary-General of Accounting and Auditing Organization for Islamic Financial Institutions (AAOIFI) and S Archer was a consultant to it.
} 
of market discipline with respect to UPSIA, in terms of UIAHs withdrawing or increasing their deposits in an IB in response to changes in the CAMEL ratios of the bank. His findings suggested that, while market discipline is ineffective, when the change in the ratios is unfavourable IB managers use the information they have about the bank's fundamentals to offer higher rates to the UPSIA holders in order to curb potential withdrawals.

In contrast, there is a fair amount of theoretical literature on the subject. Al-Deehani et al. $(1999)^{5}$ first drew attention to the benefits to shareholders in IBs of the banks being able to use UPSIA as a form of leverage that does not expose them to the risks of leverage in the form of debt. Following from that, Archer et al. (1998), pointed out the corporate governance implications of this state of affairs from the perspectives of agency and transactions costs theories. Archer et al. (2010) further analyse the implications from the perspectives of the supervision, regulation and capital adequacy of IBs. Sundararajan (2011), focusses on the "management" of profit sharing and of DCR in IBs. Hamza (2016), examined the compliance of investment deposit returns with the profit and loss sharing principle using a pooled regression model applied to a panel of sixty Islamic banks during the period 2004-2012, finding that the management of investment deposits and assets financed by profit and loss sharing (PLS) accounts (i.e. PSIA) ${ }^{6}$ is characterized by morally hazardous behaviour and excessive risk taking.

Diaw and Mbow (2011), found that the rate of return to UIAHs is correlated with the corresponding conventional interest rate. Their study includes a comparison of UIAHs' rates of return and local interest rates and shows that the means and standard deviations of these are similar. The impression is given that IBs are looking at the conventional bank interest rate and trying to match to it the rate of payout to the UIAHs, regardless of the profit they make. For example, if the bank makes a high profit for the year, it will allocate the maximum Mudarib share to its shareholders and possibly transfer part of the profit to reserves such as PERs or IRRs so as to match the market (interest) rate of payout. The reserves are used at the management's discretion to increase the UIAHs' payouts for the years with lower profits. This use of reserves will penalise UIAHs, who are denied the return they could have been paid in a year of high profits, unless they keep their account until there is a year of poor results, when funds are released from the reserves to increase the amount available for UIAHs' payouts. Such practices, and the lack of transparency surrounding them, are problematic from a corporate governance perspective.

No review of the literature on the subject would be complete without a mention of the relevant publications of the Islamic Financial Services Board. These include IFSB-3 (2006), Guiding Principles on Corporate Governance for Institutions Offering only Islamic Financial Services (2006), IFSB-4 Disclosures to Promote Transparency and Market Discipline for Institutions Offering Islamic Financial Services (2007), IFSB-9 Guiding Principles on Conduct of Business for Institutions Offering Islamic Financial Services (2009) and GN-3 Guidance Note of the Practice of Smoothing the Profits Payout to Investment Account Holders (2010). ${ }^{7}$ These publications highlight the moral hazard issues arising from the UIAHs' lack of governance rights in the presence of potential conflicts of interest between UIAH and shareholders.

\footnotetext{
${ }^{5}$ This paper was first presented as a working paper in 1996 at the University of Birmingham, UK.

${ }^{6}$ Strictly speaking, such accounts are better characterised as 'profit sharing and loss bearing', since (as explained above) the Mudarib does not share in the account holders' losses.

${ }^{7}$ All these publications were promulgated during the time when R A A Karim was the Secretary-General of the IFSB and S. Archer was a consultant to these projects.
} 
IFSB-3 proposes that IBs set up a Governance Committee to mitigate the moral hazard, and IFSB-4 focusses on the need for greater transparency to enable UIAH to make better-informed decisions about their PSIA. IFSB-9 states, among others, Principal 1 Truth, Honesty and Fairness, which requires an IB or other Islamic financial institution to "aspire to the highest standards of truthfulness, honesty and fairness in all its statements and dealings and [to] treat its customers fairly", and Principal 6 Conflicts of Interest and of Duty, whereby an IB or other Islamic financial institution is required to "recognise the conflicts of interest between it and its clients that arise from the types of products that it offers, and either avoid them or disclose and manage them, bearing in mind its fiduciary duties to investment account holders as well as shareholders." GN-3 describes the practice of smoothing the profit payouts and draws attention to the general lack of transparency on the part of IBs concerning the practice.

In principle, one would expect UIAHs as profit-sharing investors to earn a risk-adjusted rate of return on their capital not substantially inferior to that earned by shareholders. Therefore, the research tries to identify the implications for CG of UPSIAs from a practical point of view, and through certain theoretical issues, since CG is concentrated in four key principles: justice or integrity, responsibility, accountability and transparency (Hasan, 2009).

While some problems are common to financial institutions, IBs raise specific CG issues, in particular with respect to asset allocation, risk appetite, transparency in financial reporting, and potential conflicts of interest between shareholders and UIAHs. The funds of shareholders and UIAHs face the same underlying asset risk in so far as their funds are commingled with those of current accounts ${ }^{8}$ to finance the same pool of assets, and so they raise some concerns regarding governance rights. Therefore, the motivation for this research is concern about the practices of IBs in these areas, which raise specific CG issues that cannot be mitigated within the current regulations. The research also casts light on some severe anomalies in the treatment of UIAHs, which call for urgent reform of the CG of IBs. This implies that IBs have unique $\mathrm{CG}$ requirements that fit their business model and reflect the need to function effectively to address the issues concerning UIAHs.

All of this literature points to a clear need for a more extensive empirical investigation of IBs' profit sharing practices from a corporate governance and also from an ethical perspective.

\section{An Empirical Study of Profit-Sharing Practices applied to UPSIA}

\subsection{Introduction}

The study used a sample of 28 IBs in 4 Gulf Cooperation Council (GCC) ${ }^{9}$ countries plus Malaysia, as follows:

$\begin{array}{ll}\text { Bahrain } & 6 \\ \text { Kuwait } & 4 \\ \text { Qatar } & 2 \\ \text { UAE } & 4 \\ \text { Malaysia } & 12\end{array}$

\footnotetext{
${ }^{8}$ The bank (i.e. the shareholders) receives the returns and bears the risks on assets funded by current accounts.

${ }^{9}$ We are only considering retail IBs that provide UPSIAs; for example, in Kuwait there are five IBs, and we are using four of them, since Warba Bank has only recently been established and would not have sufficient data for comparison. Therefore, the four IBs represent $100 \%$ of listed IBs in the Kuwait Stock Exchange (KSE), since Warba Bank was not listed in the KSE until 2013.
} 
These countries were chosen because they account for a substantial proportion of Islamic banking assets worldwide, around 70\% according to Ernst \& Young (2016). The IBs chosen are in most cases the largest in these countries. Three of the IBs were in the Kuwait Finance House group: the parent bank in Kuwait and its subsidiaries in Bahrain and Malaysia.

Data for these banks were obtained from the Bankscope and Bloomberg databases and, where necessary, from the banks' annual reports.

The data were used to perform three different analyses:

1. A cross-sectional comparison of risk-adjusted rates of return earned by shareholders and UIAH, respectively. Risk-adjustment was made using the Coefficients of Variation $(\mathrm{CVs})$ of the respective rates of return. Shareholders' rates of return were their annual Returns on Equity (ROE), while UIAH rates of return were their annual profit payouts divided by the average balance of capital for the year. It should be noted that profits attributable to UIAH (after transfers into or out of PER or IRR) are paid out, while profits attributable to shareholders which are used to calculate ROE are in many cases only partially paid out as dividends. However, this analysis focussed on profit sharing, with the objective of ascertaining how the risk-adjusted rates of the return of the two categories of stakeholders compared. In general, the rates of return of UIAH are much lower than the ROEs of the shareholders. One justification offered for this is that the former are less risky (i.e. less volatile) than the latter, because of the widely-practiced "smoothing". In fact, our analysis shows that this is not true for more than one-third of the sample banks, i.e. for these 9 banks the risk-adjusted return of the UIAH is lower than that of the shareholders as measured by the ROE. It would therefore seem that, for these banks at least, UIAH are not being treated equitably in terms of profit sharing. ${ }^{10}$

2. A panel data analysis of the differences between the shareholders' ROEs and the UIAHs' rates of return as the dependent variable and a number of corporate governance (CG) and other variables as the independent variables. A correlation analysis showed that there was a correlation coefficient of about $60 \%$ between the amounts of these differences in rates of return and the differences in risk-adjusted returns calculated in the preceding part of the study. Our hypothesis was that CG would have an influence on the size of these differences, i.e. stronger CG would be associated with smaller differences. It appeared that while some of the CG variables did indeed have a small influence in this direction, the largest driver of the differences was the bank's Return on Average Assets (ROAA). Specifically, the larger the ROAA, the larger the

${ }^{10}$ In comparing the returns of shareholders and UIAH, one has to take into consideration the following factors, (see Karim (2008)):

1. The Mudarib share that the shareholders receive.

2. In the absence of commingling, UIAH do not partake in the returns of all the assets, but only of those which are included in the Mudarabah and are financed by their funds.

3. Shareholders, because they guarantee the funds deposited in current accounts, are the sole recipients of any returns generated from investing the excess in these funds. Shareholders, at their own discretion, may donate part of the returns from the current accounts to UPSIA, as is the case in Kuwait Finance House.

4. The Shari'ah fatwas followed by Islamic banks, such as those pertaining to determining the Mudarabah expenses and revenues and specifying the sources of funds which should be given priority in investment in cases where it is not possible to invest all the Mudarabah funds.

5. The accounting methods used by the Islamic bank to recognize the profits of investment instrument transactions and the methods of recognising asset re-measurement gains and losses. 
difference, indicating that in the more profitable years the shareholders benefited proportionately much more than the UIAH. This, again, had negative implications for the fairness of profit sharing between shareholders and UIAH in IBs.

3. The third analysis was a comparison of the shareholders' dividend yields and the UIAHs' rates of return on a risk- adjusted basis, making risk adjustments using the CVs. Dividend yield data were available for only 20 of the IBs. Again, the results were such as to raise questions regarding the fairness of the treatment of UIAH, since in 7 out of the 20 cases the CV of the UIAH's rate of return was greater (i.e. the risk-adjusted rate of return was lower) than that of the shareholders' dividend yield, while the overall mean rate of payout to UIAH was 110 basis points lower than the overall mean dividend yield.

We did not examine shareholders' stock market returns, which are a commonly used measure where firms' shares are traded in efficient markets, because not all of our sample banks were listed and for those that were listed, the GCC markets have been shown to be not even weakform efficient.

\subsection{Comparative Analysis of Risk-Adjusted Rates of Return}

Table 1 below sets out the CVs of the rates of return for shareholders and UIAH for the 28 IBs for the period 2002-2016. Table 2 and Table 3 show the results of t-tests for the rates of return and the CVs. These tables are taken from Al Hammadi (2016). 
Table 1: Adjusted Coefficients of Variation

\begin{tabular}{|c|c|c|c|c|c|}
\hline \multirow{2}{*}{$\begin{array}{r}\text { Bank per Jurisdiction } \\
\text { Bahrain }\end{array}$} & \multicolumn{2}{|c|}{ ROE Outliers } & \multicolumn{2}{|c|}{ Adjusted CV } & \multirow[t]{2}{*}{ Obs. } \\
\hline & Shareholders & UIAH & Shareholders & UIAH & \\
\hline Albaraka Islamic Bank & $-610 \% *$ & $39 \%$ & $90 \%$ & $39 \%$ & 9 \\
\hline AlSalam Bank & $70 \%$ & $104 \%$ & $70 \%$ & $104 \% * *$ & 11 \\
\hline Bahrain Islamic Bank & $1769 \% *$ & $21 \%$ & $78 \%$ & $21 \%$ & 15 \\
\hline Ithmaar Bank & $-4910 \% *$ & $26 \%$ & $164 \%$ & $26 \%$ & 13 \\
\hline Khaleeji Commercial & $194 \%$ & $34 \%$ & $111 \%$ & $34 \%$ & 12 \\
\hline КFHB & $108 \%$ & $42 \%$ & $108 \%$ & $42 \%$ & 15 \\
\hline \multicolumn{6}{|l|}{ Kuwait } \\
\hline Ahli United & $16 \%$ & $33 \%$ & $16 \%$ & $33 \% * *$ & 7 \\
\hline Boubyan & $573 \% *$ & $59 \%$ & $67 \%$ & $59 \%$ & 12 \\
\hline KFH & $56 \%$ & $59 \%$ & $56 \%$ & $59 \% * *$ & 15 \\
\hline KIB & $68 \%$ & $39 \%$ & $48 \%$ & $39 \%$ & 11 \\
\hline \multicolumn{6}{|l|}{ Qatar } \\
\hline Masraf Al Rayan & $12 \%$ & $72 \%$ & $12 \%$ & $72 \% * *$ & 10 \\
\hline Qatar Islamic Bank & $41 \%$ & $51 \%$ & $41 \%$ & $51 \% * *$ & 15 \\
\hline \multicolumn{6}{|l|}{ UAE } \\
\hline Abu Dhabi Islamic & $41 \%$ & $87 \%$ & $41 \%$ & $87 \% * *$ & 13 \\
\hline Dubai Islamic Bank & $40 \%$ & $57 \%$ & $40 \%$ & $57 \% * *$ & 15 \\
\hline Emirates Islamic Bank & $135 \%$ & $57 \%$ & $96 \%$ & $57 \%$ & 13 \\
\hline Sharjah Islamic Bank & $28 \%$ & $43 \%$ & $28 \%$ & $43 \% * *$ & 12 \\
\hline \multicolumn{6}{|l|}{ Malaysia } \\
\hline Affin Islamic Bank Berhad & $29 \%$ & $20 \%$ & $29 \%$ & $20 \%$ & 10 \\
\hline Alliance Islamic Bank Berhad & $51 \%$ & $29 \%$ & $51 \%$ & $29 \%$ & 10 \\
\hline Bank Islam Malaysia Berhad & $-577 \% *$ & $34 \%$ & $102 \%$ & $34 \%$ & 15 \\
\hline Bank Muamalat Malaysia Berhad & $75 \%$ & $15 \%$ & $52 \%$ & $15 \%$ & 15 \\
\hline CIMB Islamic Bank Berhad & $100 \%$ & $35 \%$ & $54 \%$ & $35 \%$ & 12 \\
\hline Hong Leong Islamic Bank Berhad & $27 \%$ & $17 \%$ & $27 \%$ & $17 \%$ & 11 \\
\hline KFHM & $-838 \% *$ & $46 \%$ & $112 \%$ & $46 \%$ & 12 \\
\hline Maybank Islamic Berhad & $32 \%$ & $38 \%$ & $32 \%$ & $38 \% * *$ & 9 \\
\hline OCBC Al-Amin Bank Berhad & $56 \%$ & $37 \%$ & $54 \%$ & $37 \%$ & 9 \\
\hline Public Islamic Bank Berhad & $38 \%$ & $40 \%$ & $38 \%$ & $40 \% * *$ & 9 \\
\hline RHB Islamic Bank Berhad & $28 \%$ & $23 \%$ & $28 \%$ & $23 \%$ & 12 \\
\hline Standard Chartered Saadiq Berhad & $68 \%$ & $42 \%$ & $68 \%$ & $42 \%$ & 9 \\
\hline
\end{tabular}

Note that there must be a positive result for $\mathrm{CV}$ for a meaningful comparison to be possible; however, there are some outliers in the ROE that affect the CV calculation, which need to be adjusted. Those flagged * represent return on average equity outliners, the shareholders' negative returns (outliers) were replaced with zeros. For those flagged ** (ten cases) the UIAHs have CVs higher than shareholders'. This indicates that UIAHs have a lower level of risk-adjusted rate of return. Hence, it would appear that UIAHs are not being treated fairly in these ten cases.

These coefficients of variation, and the rates of return in Table 2 and Table 3 below, were calculated after treating all negative ROEs as outliers and replacing them with zeroes. Where the overall ROE for a bank is negative, as it was in 4 cases, the CV is also negative, which cannot be interpreted. However, in some cases there were negative ROEs for some years but 
the overall ROE was positive; there were 20 such cases. We nevertheless replaced these negative ROEs with zeroes for the tables in question, but there was no change to the classification of the $\mathrm{CV}$ results when compared to those where only the overall ROEs were replaced with zeroes. In total, therefore, 27 negative ROEs were replaced with zeroes, out of 329 observations.

It was considered preferable to treat all negative ROEs as outliers ${ }^{11}$, not just those that resulted in negative $\mathrm{CVs}$, for two reasons:

1. It is better to avoid the very large positive CVs that are obtained when negative ROEs result in a very small overall mean return for a bank. These very large positive CVs are outliers that distort the data.

2. There were no negative returns for UPSIAs when the bank had a negative return on investment, underlying losses being 'smoothed' by the use of IRRs. Hence, removing all negative ROEs makes the CVs of shareholders and UIAHs more comparable.

Table 2: Shareholders' and UIAHs' adjusted rates of return 2002-2016

\begin{tabular}{lll}
\hline $\boldsymbol{t}$-Test: adjusted Rates of Return & Shareholders & UIAHs \\
\hline Mean & 0.11 & 0.03 \\
Variance & 0.00 & 0.00 \\
Banks & 28 & 28 \\
Level of Significance & 0.05 & \\
t Stat & 8.76 & \\
P-Value & $0.00^{* *}$ & \\
Standard Deviation & 0.045 & 0.006 \\
Coefficient of Variation & 0.43 & 0.19 \\
\hline
\end{tabular}

Note: P-value is smaller than the significance level of $\alpha$ of $5 \%$ and the test statistic is high, both of which indicate that there is a significant difference in mean rates of return between the two classes of stakeholders. We may note, however, that the mean rate of ROE of shareholders on the adjusted basis in this table is $11 \%$, as opposed to $8 \%$ when only overall negative mean ROEs are adjusted to zero.

11 This method was used by Diaw and Mbow (2011). 
Table 3: T-test for the difference in $\mathrm{CV}$ by bank 2002-2016

\begin{tabular}{lrr}
\hline $\boldsymbol{C V}$ T-test & Shareholders & UIAHs \\
\hline Mean & 0.61 & 0.43 \\
Variance & 0.13 & 0.04 \\
Observations & 28 & 28 \\
Level of Significance & 0.05 & \\
t Stat & 2.29 & \\
P-Value & 0.000 & \\
Standard Deviation & 0.36 & 0.21 \\
\hline
\end{tabular}

Difference in the coefficient of variation between shareholders and UIAHs for returns 2002-2016 where the p-value is smaller than the significance level of $\alpha(5 \%)$, which indicates significant difference in risk-adjusted return.

The 10 cases where the CV of UIAH rates of return were higher than those of shareholders are those flagged by double asterisks $(* *)$ in Table 1 . These cases represent more than one-third of the sample. In addition, there were 2 cases where the CV of the UIAHs' rates of return was only slightly lower than that of the shareholders' rates of return. Given these data, the proposition that the higher rates of return received by shareholders are justified by being more risky than those received by UIAH is not generally borne out, being true in only $61 \%$ of the cases. This is in spite of the practice of "smoothing" the returns of the UIAH, which, where the PER or IRR is used, means that the UIAH are in effect being obliged to "smooth" their own returns, while having no control over this process, and with no forgoing by the bank of its Mudarib share (except to the extent that appropriations to the PER reduce the amount of profit on which the Mudarib percentage share in based). It is worth reiterating that because of the commingling of Mudarabah-funded assets with other assets on the bank's balance sheet, UIAH and shareholders are exposed to the same asset risks.

These findings imply that the CG of IBs is not effective in protecting the interests of UIAH as against those of the shareholders. However, it could be argued that the shareholders' ROE is composed partly of retained profits, the value of which is hard to determine in the absence of efficient stock markets in which their value would be reflected in the share price.

The UIAHs returns, being paid out, are more akin to dividends, so that it could be argued that a fairer comparison would be between UIAHs' rates of return and shareholders' dividend yield rates, both on a risk-adjusted basis. Such a comparison is made in Section 6, but does not point to conclusions different from those made above. Moreover, the portion of shareholders' profits that are not paid out, i.e. retained profits, presumably offer some benefit to shareholders (even if this cannot readily be measured in inefficient stock markets), but not to UIAH. According to Hassan et al. (2003), GCC stock markets are relatively small, trade infrequently and at low volumes, and there are few listed companies, which indicates a thin market. Also Abdmoulah (2010) found that the GCC markets are highly sensitive to previous stock prices (in the absence of 'random walk') ${ }^{12}$, and are thus weak-form inefficient (i.e. not even weak-form efficient) markets.

\footnotetext{
12 'Random walk' is a market situation where the future directions of the stocks' movements cannot be predicted on the basis of past movements, i.e. an absence of serial autocorrelation (Malkiel, 1999).
} 


\section{Research Methodology}

This section uses a panel data analysis to examine the extent to which certain variables familiar from the CG literature help to explain the sizes of the annual differences, bank by bank, between the shareholders' ROEs and the UIAHs' rates of return (the "spreads" of the rates of return). One might expect that stronger CG would be associated with better protection of UIAHs' interests, resulting in smaller spreads between shareholders' and UIAHs' rates of return. This is what we seek to ascertain. Using dataset of 329 bank-year observations, we run regression with panel data, which enables us to fit regression models with adjusted R-squared of $70 \%$ or more. We use 'fixed effects' models ${ }^{13}$, since the benefit of using a fixed effects model for the spread of the rates of return is that it allows the heterogeneity among individual banks to be reflected in the intercept for each bank value $\left(\alpha_{i}\right)$ across sectional fixed effects (Gujarati, 2012).

\subsection{Hausman Test}

It is interesting to see whether fixed effects or a random effects model is more significant or more appropriate to use, and better for our data. A Hausman specification test could be performed to compare between the two models, to examines if the individual effects are uncorrelated with other regressors in the model (Park, 2011). For example, if individual effects are correlated with other regressor, that is random effects would violate a Gauss-Markov assumption and the model is no longer BLUE.

\subsection{Hausman Hypothesis Test}

Null hypothesis: Random-effects model is appropriate.

Alternative hypothesis: fixed effects model is appropriate.

If the null hypothesis is rejected, then the alternative hypothesis or fixed effects model would be preferred over random effects model.

\section{Table 4: Hausman Test}

Correlated Random Effects - Hausman Test

Equation: RANDOM

Test cross-section random effects

\begin{tabular}{llll}
\hline \hline Test Summary & Chi-Sq. Statistic & Chi-Sq. d.f. & Prob. \\
\hline \hline Cross-section random & 13.342346 & 7 & $0.0442 * *$ \\
\hline \hline
\end{tabular}

**The p-value for the Hausman test is less than $5 \%$ which indicate that random effects is not appropriate and the fixed effects would be a better test.

\footnotetext{
${ }^{13}$ Based on Hausman Test, see Hausman section The p-value for the Hausman test is less than 5\% which indicate that random effects is not appropriate and the fixed effects would be a better test in our model.
} 
Therefore, the Hausman test rejects the null hypothesis and the use of a fixed effects model would be favoured over that of a random effects model to explain the difference in the rates of return between shareholders and investment account holders.

\subsection{The regression model}

Panel (A): Individual Fixed Effects Regression Equation

Return spread $_{i t}$ (shareholders' rate of returns minus UIAH rate of returns) $=\alpha_{i}$

$+\beta_{1}$ ratio of non executive members in the $B O D_{i t}+\beta_{2}$ CEO Duality

$+\beta_{3} B O D$ size $_{i t}+\beta_{4}$ existence of $C G$ committe $_{i t}+\beta_{5} R O A_{i t}$

$+\beta_{6}$ total equity to total assets ${ }_{i t}+\beta_{7}$ total deposits to total assets $s_{i t}$

$+\beta_{8}$ total assets $_{i t}+u_{i t}$

Panel (B): Regression Equation including the Country Dummy ${ }^{14}$

Return Spread ${ }_{\text {it }}$ (shareholders' rate returns minus UIAH rate of returns) $=$ $\beta_{1}$ ratio of non executive members in the $B O D_{i t}+\beta_{2} C E O$ Duality $+\beta_{3} B O D$ size $_{i t}+$ $\beta_{4}$ existence of CG committe $e_{i t}+\beta_{5} R O A_{i t}+\beta_{6}$ total equity to total assets ${ }_{i t}+$ $\beta_{7}$ total deposit to total assets $s_{i t}+\beta_{8}$ total assets $_{i t}+\beta_{9}$ country dummy $_{k}+u_{i t}$

\subsection{Dependent Variable}

The difference in rates of return between the shareholders and UIAHs ("spread") is a variable of interest in its own right and also as a proxy for the difference between the CVs.

Return Represents the dependent variable that is random or stochastic and has a Spread normal probability distribution, which is the rate of return difference between shareholders and UIAHs in different Islamic banks for the past 15 years.

A correlation analysis between the size of this spread and the differences in the CVs analysed showed a correlation coefficient of $-59.2 \%$. Thus, a smaller difference in CVs (such that the $\mathrm{CV}$ of UIAHs' rates of return is close to, or even greater than, the CV of shareholders' rates of return) is associated with a higher rate of return difference.

\subsection{Independent Variables}

$\boldsymbol{N O N} \boldsymbol{N}_{-} \boldsymbol{E} \boldsymbol{X}_{-} \boldsymbol{D}$ Ratio of non-executive directors in the Board of Directors (BOD). Proportion of non-executive members in the BOD; the data were collected from the banks' annual reports, by dividing the number of non-executive directors by the total number of BOD members.

\footnotetext{
${ }^{14}$ Group A - Bahrain and Malaysia, Group B - Kuwait, Qatar and UAE.
} 
CEO Dual CEO Duality; a dummy variable that takes a value of zero in each sample bank refer to the absence of a duality role, i.e. that there were a separate Chief Executive Officer (CEO) and chair, and one otherwise (duality: same chair and CEO held simultaneously for the bank).

B Size $\quad$ The size of the BOD; total number of members on the board.

CG COMM Existence of a Governance committee, attached to the BOD, as a dummy variable. The IFSB Standard on Corporate Governance (IFSB-3) recommends the establishment of such a committee to oversee the fair treatment of IAH. The dummy takes a value of one in the model when the bank has a Governance Committee, and zero otherwise.

$\boldsymbol{R O A A}$ Return on average assets (net income/total asset) to measure the performance of the bank, which shows the profit earned per dollar of assets, reflecting the management's ability to make profits by utilising the bank's assets to achieve a good return. The data on ROAA was taken from the Bankscope database.

TETA Equity ratio, which is ratio of total equity to total assets, to measure the leverage effect. The data was acquired from the banks' annual reports by dividing total equity by total assets.

TDTA Ratio of total deposits to total assets or the Mudarabah funds ratio (UPSIA/total assets). If the bank is financed largely by profit-sharing investment accounts, we expect that this might generate a big difference in return. The bank may use this leverage to boost the return to shareholders at the expense of UIA. Depending on market competition and the Islamic bank's strategy, if the Islamic bank manages to get more UPSIA and pays more returns to them, shareholders are expected to receive a better return, other things being equal.

TA Total assets which represent bank size.

Group B Country dummy variable, which takes a value of one for banks located in Bahrain and Malaysia, and zero otherwise. The economic rationale for using country dummy variable is that we expect that country would have an effect on the difference in rates of return, since Bahrain and Malaysia are betterregulated countries with more competition, and it would appear that UIAHs are treated better there than in other countries. 


\subsection{Descriptive Statistics}

The following table shows the correlation among the explanatory variables that have been used in the regression model:

\section{Table 5: Correlation between variables}

\begin{tabular}{|c|c|c|c|c|c|c|c|c|}
\hline Variables & $N O N \_E X \_D$ & $L S$ & B_SIZE & CG_COMM & $R O A A$ & TETA & TDTA & $T A$ \\
\hline$N O N \_E X \_D$ & 1 & & & & & & & \\
\hline CEO Dual & -0.1764 & 1 & & & & & & \\
\hline B_SIZE & 0.0171 & 0.0844 & 1 & & & & & \\
\hline CG_COMM & -0.1119 & -0.0940 & 0.2266 & 1 & & & & \\
\hline$R O A A$ & 0.1589 & 0.0732 & 0.0173 & -0.0966 & 1 & & & \\
\hline TETA & 0.0508 & 0.0047 & 0.0499 & -0.0098 & 0.5253 & 1 & & \\
\hline$T D T A$ & 0.1213 & -0.0285 & 0.0486 & 0.0832 & 0.0301 & 0.0249 & 1 & \\
\hline$T A$ & 0.2068 & 0.0266 & 0.0407 & 0.1448 & 0.0135 & -0.1842 & 0.2237 & 1 \\
\hline
\end{tabular}

The table shows the Pearson correlation coefficient between the explanatory variables. Note that TETA and TDTA are somewhat correlated since both denominators are the total assets.

\section{Table 6: Sample statistics}

\begin{tabular}{l|cccccccccc}
\hline \multicolumn{1}{c}{ Variables } & Mean & Median & Max & Min & SD & Skewness & Kurtosis & Jarq-B & Prob & Obs \\
\hline NON_EX_D & 0.90 & 0.89 & 1.00 & 0.33 & 0.11 & -2.47 & 12.06 & 1472.8 & 0.00 & 332 \\
CEODual & 0.04 & 0.00 & 1.00 & 0.00 & 0.20 & 4.57 & 21.90 & 6135.1 & 0.00 & 334 \\
B_SIZE & 8.37 & 9.00 & 13.00 & 4.00 & 1.73 & -0.07 & 3.05 & 0.28 & 0.87 & 332 \\
CG_COMM & 0.27 & 0.00 & 1.00 & 0.00 & 0.44 & 1.05 & 2.10 & 71.97 & 0.00 & 332 \\
ROAA & 0.01 & 0.01 & 0.11 & -0.12 & 0.02 & 0.27 & 10.76 & 907.39 & 0.00 & 360 \\
TETA & 0.15 & 0.11 & 1.00 & -0.02 & 0.13 & 3.59 & 20.43 & 5329.0 & 0.00 & 360 \\
TDTA & 11.44 & 0.69 & 720.00 & 0.03 & 83.34 & 7.70 & 61.00 & 53571.3 & 0.00 & 357 \\
TD & 8256.3 & 4125.9 & 58681.4 & 37.6 & 10580.9 & 2.44 & 9.16 & 927.9 & 0.00 & 360 \\
\hline
\end{tabular}

Descriptive statistics for regression variables.

The result tables below show that some variables have explanatory power for the difference in rates of return between the two classes of stakeholders. What is interesting in the CG variables is that CEO duality. On one hand, CEO duality has a positive sign when there is a duality in chair and CEO (i.e. the same person chairs the board and is CEO): the UIAHs appear to do worse (i.e. the difference is bigger) in that case than when the bank has separate CEO and chairperson. For example, if we look at the historical payouts by KFH-Kuwait when they had the same chair-CEO, we see that the bank used to give higher rates of return to UIAHs (the bank had higher profit as well, and shareholders also received high ROE). But, rather than the actual rate of return to UIAHs, we are considering the rate of return to shareholders minus the rate of return to UIAHs, and the positive coefficient in CEO duality, meaning the difference is bigger when there is a same person as chair and CEO. This finding is in opposition to the theory of stewardship discussed earlier and the empirical study by Donaldson and Davis (1991), which shows that a single CEO-chair tends to be better, although in our case it is better for UIAHs to have separate CEO/chair; however, UIAHs cannot do anything to reward the management. In fact, as we discover later, it is mainly the ROAA that is driving the results. 
Table 7: Panel (A) Individual Fixed Effects with no country dummy

\begin{tabular}{l|rrrr}
\hline Variable & Coefficient & Std. Error & t-Statistic $^{\mathbf{1 5}}$ & \multicolumn{1}{c}{ Prob. } \\
\hline NON_EX_D & -0.0474 & 0.0250 & -1.8993 & $0.0585^{* *}$ \\
CEODDual & 0.0247 & 0.0124 & 1.9926 & $0.0472^{*}$ \\
B_SIZE & 0.0017 & 0.0018 & 0.9496 & 0.3431 \\
CG_COMM & -0.0039 & 0.0050 & -0.7857 & 0.4327 \\
ROAA & 2.6997 & 0.1346 & 20.0555 & $0.0000^{*}$ \\
TETA & -0.3383 & 0.0341 & -9.9222 & $0.0000^{*}$ \\
TDTA & 0.0000 & 0.0000 & -1.0705 & 0.2853 \\
TA & 0.0000 & 0.0000 & -1.1214 & 0.2630 \\
R-squared & $79 \%$ & & & \\
Adjusted $R$-squared & $76 \%$ & & & \\
S.E. of regression & 0.0460 & & & \\
F-statistic & 0.1013 & & & \\
Prob(F-statistic) & 0.0956 & & & \\
Mean dependent variable & 31.1230 & & & \\
S.D. dependent variable & 0.0000 & & & \\
\hline Note: & & & & \\
\hline
\end{tabular}

Note: *denotes significance at the 5\% level, and **denotes significance at the $10 \%$ level, using GLS weights to control for heteroscedasticity. Sample period between 2002 and 2016; crosssections include 28 banks with a total panel (unbalanced) of 329 observations. Our dataset is unbalanced since not all the banks have 15 years of observations; some IBs are relatively new or have just converted to being an Islamic bank.

\begin{tabular}{l|rrrr}
\multicolumn{5}{c}{ Table 8: Panel (B) Individual Fixed Effects with country effect } \\
\hline \multicolumn{1}{c}{ Variable } & Coefficient & Std. Error & t-Statistic & \multicolumn{1}{c}{ Prob. } \\
\hline NON_EX_D & 0.0029 & 0.0186 & 0.1553 & 0.8766 \\
CEODual & 0.0178 & 0.0104 & 1.7014 & $0.0898^{* *}$ \\
B_SIZE & -0.0006 & 0.0011 & -0.4829 & 0.6295 \\
CG_COMM & -0.0161 & 0.0044 & -3.6283 & $0.0003^{*}$ \\
ROAA & 3.1078 & 0.1296 & 23.9895 & $0.0000^{*}$ \\
TETA & -0.3872 & 0.0265 & -14.6218 & $0.0000^{*}$ \\
TDTA & 0.0000 & 0.0000 & 0.4117 & 0.6808 \\
TA & 0.0000 & 0.0000 & 4.1033 & $0.0001^{*}$ \\
GROUPB & -0.0066 & 0.0048 & -1.3548 & 0.1764 \\
R-squared & $70 \%$ & & & \\
Adjusted R-squared & $70 \%$ & & & \\
S.E. of regression & 0.0509 & & & \\
F-statistic & 84.5582 & & & \\
Prob(F-statistic) & 0.0000 & & & \\
Mean dependent var & 0.1033 & & & \\
S.D. dependent var & 0.1001 & & & \\
\hline
\end{tabular}

Note: *denotes significance at the 5\% level and ** at the $10 \%$ level, using GLS weights to control for heteroscedasticity. Group B contains Kuwait, Qatar and the UAE.

The regression results in the tables above show high goodness of fit, and indicate that some of the CG variables were associated with the size of the differences in the rates of return. The country dummy was not significant but had the expected sign (Group B countries had higher differences). Leadership structure (duality versus non-duality) was influential with or without the dummy variable, and had the expected sign (non-duality was associated with lower differences). Board size had no influence, and was not significant although the sign changed when the country dummy was introduced. The ratio of non-executive directors also had little

\footnotetext{
${ }^{15}$ Care needs to be taken in interpreting t-statistics for panel data because of a potential clustering problem and lack of independence of observations.
} 
influence, having a small coefficient the sign of which changed when the country dummy was introduced. The existence of a Governance Committee was hardly influential, especially in the absence of the country dummy, having a small coefficient, but was significant and had a larger coefficient with the country dummy, and had the expected sign (its presence being associated with smaller differences).

However, it is the financial variables that display the greatest explanatory power. Return on assets has a large coefficient and a positive sign, which indicates that when the rate of return on assets is high, this increases the difference between the shareholders' rate of return and that of the UIAH. In other words, the shareholders receive the lion's share of the higher profits through being given a Mudarib share equal or close to the maximum. When profits are lower, the bank reduces its Mudarib share. Total equity to total assets has a negative sign, indicating that higher leverage is associated with greater differences between shareholders' and UIAHs' rates of return.

These findings imply that the concept of "profit sharing" as applied by IBs in respect of UPSIA is far from being straightforward. The division of profits between the shareholders and the UIAH appears to depend, to a very significant degree, on the exercise of discretion by the IB's management, taking advantage of the high maximum Mudarib share permitted by contract to pass most or all of the benefit of the more profitable years to the shareholders.

\section{A Comparison of Shareholders' Dividend Yield and UIAHs' Rates of Return}

While our examination of profit sharing practices in the sections above raises some issues about the fairness of such practices, it could be argued that the profit shares of the shareholders are accounting numbers that include a substantial unrealised element in the form of retained profits. Yet it is reasonable to assume that the retained profits represent some real benefit to shareholders, otherwise it is hard to see why they would be retained rather than distributed. Moreover, any such benefit would accrue only to shareholders, not to UIAH.

Nevertheless, given that the UIAHs' returns are paid out, because the Islamic bank cannot retain UIAH share of profits (except in the PER and IRR), it is of interest to compare the UIAHs' rates of return to the shareholders' dividend yield rates, on a risk adjusted basis, that is, using the CVs of the respective rates of return. Dividend data were available for 20 out of the 28 IBs in our sample, as shown in Table 4.6 below. They show that for as many as 7 out of the 20 banks, i.e. $35 \%$, the CV of the UIAHs' payouts is higher than that of the dividend yields. (In 2 other cases, the CV of the UIAHs' return is only slightly lower than that of the dividend yield.) This may be considered to be a surprising result, given the practice of "smoothing". However, it indicates that the conclusions one may draw from the examination of profit sharing, regarding the inequitable treatment of UIAH in a significant proportion of cases, are corroborated by the comparison of UIAHs' returns and dividend yield rates.

The overall mean dividend yield rate was $4.0 \%$, compared to the overall mean UIAH rate of return of $2.90 \%$. The difference of 110 basis points in favour of the shareholders may perhaps be considered as a price paid by UIAH for the asset management services of the bank. However, one should recall that the profits out of which the dividends are paid are derived to a substantial degree from the Mudarib share of the return on the Mudarabah assets, and, while shareholders presumably receive some additional benefit from retained profits, none of this goes to the UIAH. Thus, the bank's remuneration for asset management is, in general, considerably more than 110 basis points. 
Table 9: Dividend yield and UIAHs

\begin{tabular}{l|rrrrrr}
\multicolumn{1}{c}{ 2002-2016 } & \multicolumn{3}{c}{ Dividend yield } & \multicolumn{3}{c}{ IAH pay-out } \\
\hline Bank & Mean & SD & CV & Mean & SD & CV \\
\hline BARK & 0.04 & 0.01 & $24 \%$ & 0.03 & 0.02 & $52 \% * *$ \\
SALM & 0.07 & 0.03 & $44 \%$ & 0.02 & 0.02 & $104 \% * *$ \\
BAHN & 0.04 & 0.01 & $36 \%$ & 0.03 & 0.01 & $21 \%$ \\
ITHM & 0.07 & 0.03 & $49 \%$ & 0.04 & 0.01 & $26 \%$ \\
AHLI & 0.05 & 0.02 & $31 \%$ & 0.03 & 0.01 & $33 \% * *$ \\
KFH & 0.03 & 0.01 & $31 \%$ & 0.03 & 0.02 & $59 \%$ \\
KIB & 0.02 & 0.01 & $55 \%$ & 0.03 & 0.01 & $39 \%$ \\
MASF & 0.06 & 0.04 & $57 \%$ & 0.03 & 0.02 & $72 \% * *$ \\
QATR & 0.04 & 0.03 & $61 \%$ & 0.04 & 0.02 & $51 \%$ \\
DHABI & 0.05 & 0.03 & $54 \%$ & 0.03 & 0.02 & $87 \% * *$ \\
DUBAI & 0.06 & 0.03 & $61 \%$ & 0.02 & 0.01 & $57 \%$ \\
SHAJ & 0.05 & 0.02 & $39 \%$ & 0.03 & 0.01 & $43 \% * *$ \\
AFFN & 0.02 & 0.02 & $65 \%$ & 0.03 & 0.01 & $40 \%$ \\
ALLN & 0.03 & 0.01 & $48 \%$ & 0.03 & 0.01 & $22 \%$ \\
ISLM & 0.03 & 0.02 & $53 \%$ & 0.02 & 0.01 & $33 \%$ \\
MUAT & 0.02 & 0.01 & $54 \%$ & 0.03 & 0.00 & $14 \%$ \\
CIMB & 0.02 & 0.01 & $44 \%$ & 0.03 & 0.01 & $35 \%$ \\
HONG & 0.03 & 0.01 & $51 \%$ & 0.03 & 0.01 & $16 \%$ \\
MAY & 0.04 & 0.02 & $46 \%$ & 0.03 & 0.01 & $35 \%$ \\
OCBC & 0.03 & 0.01 & $33 \%$ & 0.03 & 0.01 & $35 \% * *$ \\
\hline Mean & $\mathbf{4 . 0 \%}$ & & & $\mathbf{2 . 9 \%}$ & & \\
\hline SOurce B & & & & & \\
\hline
\end{tabular}

Source: Bloomberg and Annual Report for \% pay-out for 2002-2016. The interest here is in how UIAHs' and shareholders' rates of return vary with respect to their level of risk-adjusted rates of return, not only the different levels of the rates of return. To measure the level of risk adjustment is by using the $\mathrm{CV}$, which is the SD divided by the mean. As can be seen ** 7 banks out of 20 the CV of UIAHs' returns were higher, which indicates that UIAHs are not treated fairly per the risk adjusted return.

\section{Summary and Conclusions}

This study undertakes an analysis and comparison of risk-adjusted returns to examine whether, in the absence of governance rights, the UIAH are treated equitably compared to shareholders in IBs and tests whether the current practice of CG in IBs does balance the rights of UIAHs with those of shareholders. One way to look at the governance issues was to examine the difference in the rates of return between shareholders and UIAHs. The study also attempted to ascertain what drives the difference in the risk-adjusted profit distribution between shareholders and UIAHs and the extent to which independent CG variables influence this difference.

The practices of IBs reviewed in Section 2 and the literature reviewed in Section 3 raised some important corporate governance issues regarding the fair treatment of UIAH in IBs, given their lack of governance rights. The analyses in Section 4 showed that there are indeed reasons to believe that in a significant proportion of cases IBs are not treating their UIAH equitably. In more than one third of the sample IBs, the risk-adjusted rates of return paid to the UIAH were inferior to those accruing to the shareholders, in the form either of ROE or of dividend yield. More generally, the practice of profit sharing takes place within a system whereby, thanks to the contractual Mudarib share being set as a high maximum rate, the profit share of the UIAH is largely at the discretion of the IB's management, who tend to pay a low rate that is comparable to that on a conventional deposit although UIAH are exposed to risks to which conventional depositors are not exposed. In effect, UPSIA are typically used by IBs as a form 
of very low-risk leverage, since the banks do not have any obligation to pay returns to UIAH in the absence of profits, and in any case may use reserves taken from prior-year UIAH profits to pay returns in years when profits are lacking. In the absence of governance rights, the only safeguard UIAH might have would be effective competition between IBs for their funds together with transparency and market discipline, but the evidence suggests that these are insufficient. The panel data analysis in Section 5 showed that the presence of a Governance Committee appears to improve matters somewhat for UIAH, and that in general they seem to be slightly better treated in Bahrain and Malaysia, thanks to greater competition and more effective regulation; but these effects are small. Consequently, IBs face what might be described as an ethical issue in their treatment of UIAH.

The results have policy implications and should help the supervisory authorities or central banks better to understand how IBs are treating UIAHs, which may also help them to evaluate the current CG standards and practices. The research also contributes to the existing body of knowledge concerning CG in IBs and to filling the gaps in the literature relating to UIAHs' lack of governance rights and lack of transparency, which lead to unfair treatment in terms of return and to ambiguity regarding their status and lack of rights. UIAHs do not have any governance rights (other than the right to withdraw their funds) and there is a lack of transparency in banks' dealings with them. The background of the research has centred on the issue of the fair treatment of UIAHs from the CG perspective of the rights of stakeholders. As the results of the research show, this lack of governance rights and transparency is associated not only with unfair treatment in a significant number of cases, but also with ambiguity regarding their status and rights.

The research has useful implications for policymaking, especially as regards the regulation and supervision of how UIAHs are paid returns on their funds, which arguably calls for urgent reform of the CG of IBs. It sheds light on the effect of UIAHs' lack of governance rights and how they may be exposed to a potential conflict of interest with the management of IBs, ways in which management may look after the interests of shareholders at the expense of UIAHs. This points to a need to have effective internal governance, such as by establishing CG committees attached to the BOD to monitor and act on behalf of PSIA, as recommended by the IFSB (although our analysis did not indicate that CG committees had much influence). There is also a need to increase transparency in terms of profit allocation between UPSIA and shareholders, to disclose information on the smoothing mechanism, including the use of reserves such as PER and IRR. In addition, UIAH could benefit from depositor protection, using Takaful-based insurance.

Islamic finance has the potential to offer a more ethically-based form of financial services industry compared to conventional financial services, which have earned a reputation for unbridled greed and opportunism in recent years. The IFSB's IFSB-9 on Conduct of Business, as quoted above, provides some pertinent guidelines. However, to live up to that potential it would seem that IBs need, among other things, to treat their UIAH more equitably. One alternative might be an increasing use of CMT-based term deposits; while on one hand this would bring the business model of IBs closer to that of conventional banks it would, on the other hand, avoid the governance and ethical problems we describe above ${ }^{16}$.

\footnotetext{
16 However, this use of CMT-based term deposits raises other difficulties in that some Shari'ah scholars, notably including the members of the OIC Fiqh Academy in their resolution of 30 April 2009, take the view that such 'organised' uses of Commodity Murabahah are not compliant with the Shari'ah.
} 


\section{References}

Abdmoulah, W. (2010). Testing the Evolving Efficiency of Arab Stock Markets. International Review of Financial Analysis, 19, 25-34.

Al-Deehani, T., Karim, R. A. A. \& Murinde, V. (1999). The Capital Structure of Islamic Banks under the Contractual Obligation of Profit Sharing. International Journal of Theoretical and Applied Finance, 2, 243-283.

Al-Sadah, A. K. (2008). Corporate Governance of Islamic Banks: Its Characteristics and Effects on Stakeholdrs and the Role of Islamic Bank Supervisors. PhD Dissertation. Surrey: University of Surrey.

Alaeddin, O. (2015). Market Discipline and Islamic Banks: The Case of Profit Sharing Investment Accounts. Unpublished PhD Thesis, INCEIF, Kuala Lumpur, Malaysia.

Alhammadi, S. (2016). Corporate Governance Dilemma with Unrestricted Profit Sharing Investment Accounts in Islamic Banks. PhD thesis, ICMA Centre, Henley Business School, University of Reading.

Archer, S., Karim, R. A. A. \& Al-Deehani, T. (1998). Financial Contracting, Governance Structures and the Accounting Regulation of Islamic Banks: An Analysis in Terms of Agency Theory and Transaction Cost Economics. Journal of Management and Governance, 2, 149-170.

Archer, S., Karim, R. A. A. \& Sundararajan, V. (2010). Supervisory, Regulatory, and Capital Adequacy Implications of Profit-Sharing Investment Accounts in Islamic Finance. Journal of Islamic Accounting and Business Research, 1, 10-31.

Diaw, A. \& Mbow, A. (2011). A Comparative Study of the Returns on Mudharabah Deposit and on Equity in Islamic Banks. Humanomics, 27, 229-242.

Donaldson, L. \& Davis, J. H. (1991). Stewardship Theory or Agency Theory: Ceo Governance and Shareholder Returns. Australian Journal of management, 16, 49-64.

Gujarati, D. N. (2012). Basic Econometrics. Tata McGraw-Hill Education.

Hamza, H. (2016). Does Investment Deposit Return in Islamic Banks Reflect Pls Principle? Borsa Istanbul Review, 16, 32-42.

Hasan, Z. (2009). Corporate Governance: Western and Islamic Perspectives. International Review of Business Research Papers, 5, 277-293.

Hassan, K. M., Al-Sultan, W. S. \& Al-Saleem, J. A. (2003). Stock Market Efficiency in the Gulf Cooperation Council Countries (GCC): The Case of Kuwait Stock Exchange. Development, 1.

IFSB-3 (2006). Guiding Principles on Corporate Governance for Institutions (Other Than Insurance Institutions) Offering Only Islamic Financial Services. Kuala Lumpur: Islamic Financial Services Board.

IFSB-4 (2007). Disclosures to Promote Transparency and Market Discipline for Institutions Offering Islamic Financial Services. Kuala Lumpur: Islamic Financial Services Board.

IFSB-9 (2009). Guiding Principles on Conduct of Business for Institutions Offering Islamic Financial Services Kuala Lumpur: Islamic Financial Services Board.

IFSB-GN3 (2010). Guidance Note on the Practice of Smoothing the Profits Payout to Investment Account Holders. 
Karim, R. A. A. (1994). Accounting Aspects of Profit Allocation Methods between Shareholders and Investment Account Holders in Islamic Banks. Journal of Administrative and Economic Science, 10, 165-97.

Malkiel, B. G. (1999). A Random Walk Down Wall Street: Including a Life-Cycle Guide to Personal Investing. WW Norton \& Company.

Park, H. M. (2011). Practical Guides to Panel Data Modeling: A Step-by-Step Analysis Using Stata. Public Management \& Policy Analysis Program, International University of Japan.

Sundararajan, V. (2011). Profit Sharing Investment Accounts-Measurement and Control of Displaced Commercial Risk in Islamic Finance. Islamic Research \& Training Institute (IRTI), 19, 41.

Williamson, O. E. (1996). The Mechanisms of Governance. Oxford University Press. 